\title{
Long-term outcomes of embolization of type II endoleaks
}

\author{
Resultados em longo prazo de embolização de endoleaks tipo II
}

Eduardo da Silva Eli , Júlia Jochen Broering ${ }^{1}$, David Ernesto Timaran², Carlos Hernando Timaran²

\begin{abstract}
Background: Type II endoleaks are common after endovascular aortic aneurysm repair. The purpose of this study was to assess the long-term outcomes of embolization of type II endoleaks using different techniques and materials. Methods: Between 2003 and 2015, 31 patients underwent embolization of type II endoleaks, in a total of 41 procedures. Patients underwent transarterial or translumbar embolization using Onyx ${ }^{\circledR} 18$, Ony $x^{\circledR} 34$, coils, Amplatzer ${ }^{\circledR}$ plug and/or thrombin. Embolization success was defined as no endoleak reintervention. The chi-square test and Fisher's exact test were used for statistical analysis. Results: Median embolization time after aortic aneurysm repair was 14 months. Fifteen (36\%) embolization interventions were performed using Ony $x^{\circledR} 18$; seven (17\%) with coils and Ony $x^{\circledR} 34$; six (14\%) with Ony $x^{\circledR} 34$; four (10\%) with coils and Ony ${ }^{\circledR} 18$; four with Ony ${ }^{\circledR} 18$ and Ony ${ }^{\circledR} 34$; three (7\%) with coils and thrombin; one (2\%) with coils; and one (2\%) with an Amplatzer ${ }^{\circledR}$ device. Eleven patients (35\%) required reintervention. The embolization success rate was $71.43 \%$ (10) for patients with lumbar arteries as the source of the endoleak, 80\% (8) for the inferior mesenteric artery and 40\% (2) when both inferior mesenteric artery and lumbar arteries were the culprit vessels $(p<0.05)$. There was no statistically significant difference with regards to type of embolization, embolic material or type of previous aortic repair. Conclusions: Endovascular treatment of type II endoleaks is challenging and reintervention is needed in up to $36 \%$ of patients. Endoleaks supplied by both the inferior mesenteric artery and the lumbar arteries have a lower rate of success.
\end{abstract}

Keywords: type II endoleak; embolization; endoleak.

\begin{abstract}
Resumo
Contexto: Endoleaks tipo II são frequentes após o reparo endovascular de aneurismas de aorta. Objetivo: O objetivo deste estudo foi comparar o sucesso da embolização de endoleaks tipo Il utilizando diferentes técnicas e materiais. Métodos: Entre 2003 e 2015, 31 pacientes foram submetidos a embolização de endoleak tipo Il, totalizando 41 procedimentos. Esses procedimentos foram conduzidos por acesso translombar, acesso femoral ou uma combinação de ambos, utilizando Ony ${ }^{\circledR} 18$, Onyx ${ }^{\circledR} 34$, coils, plugue vascular Amplatzer ${ }^{\circledR}$ e trombina como material emboligênico. Sucesso foi definido como ausência de reintervenção. O teste de qui-quadrado e o teste exato de Fisher foram utilizados para a análise estatística. Resultados: $O$ tempo médio entre a correção do aneurisma de aorta e a embolização foi de 14 meses. Quinze (36\%) das intervenções utilizaram Onyx ${ }^{\circledR} 18$; sete (17\%) utilizaram coils e Ony ${ }^{\circledR} 34$; seis (14\%) utilizaram Onyx ${ }^{\circledR} 34$; quatro (10\%) utilizaram coils e Onyx ${ }^{\circledR} 18$; quatro $(10 \%)$ usaram Onyx ${ }^{\circledR} 18$ e Onyx ${ }^{\circledR} 34$; e três $(7 \%)$ usaram coils e trombina; um (2\%) usou coils e um (2\%) usou Amplatzer ${ }^{\circledR}$. Onze pacientes (35\%) necessitaram de reintervenção. A taxa de sucesso foi de 71,43\% (10) para os pacientes com as artérias lombares como fonte do endoleak, $80 \%$ (8) quando a fonte era a artéria mesentérica inferior e $40 \%$ (2) quando havia combinação de ambas $(p<0,05)$. Não houve diferença estatisticamente significativa com relação ao tipo de embolização, material emboligênico e tipo de reparo da aorta para a correção do aneurisma. Conclusões: A terapia endovascular de endoleaks tipo II é um desafio, sendo necessária reintervenção em até 36\% dos casos. A taxa de sucesso é menor quando o endoleak é nutrido pela combinação das artérias lombares e da artéria mesentérica inferior.
\end{abstract}

Palavras-chave: endoleak tipo Il; embolização; endoleak.

\footnotetext{
${ }^{1}$ Universidade Federal de Santa Catarina - UFSC, Florianópolis, SC, Brazil.

${ }^{2}$ University of Texas Southwestern - UTSW, Vascular Surgery Department, Dallas, Texas, USA.

Financial support: None.

Conflicts of interest: No conflicts of interest declared concerning the publication of this article

Submitted: October 22, 2015. Accepted: December 08, 2015.
}

The study was carried out using records filed at the Parkland Memorial Hospital, University of Texas Southwestern Hospital and VA Medical Center, located in Dallas, Texas, USA. 


\section{INTRODUCTION}

Endovascular Abdominal Aortic Aneurysm Repair (EVAR) is now an accepted treatment option in patients with favorable anatomy. ${ }^{1-3}$ However, the need for a strict follow-up regime, using expensive imaging exams, and the rate of reinterventions, predominantly related to endoleaks, still limit its cost-effectiveness ratio. ${ }^{1,3}$

Endoleaks are the most common complication associated with EVAR and they are reported in up to $40 \%$ of initially successful procedures. ${ }^{4}$ They can be classified according to their causative mechanisms as follows: type I endoleaks are caused by mechanical separation of the prosthesis components from the native vessel; type II endoleaks are caused by persistent perfusion of the aneurysm sac by patent lumbar arteries or lower branches of the inferior mesenteric artery (IMA) and may involve a range of types of flow; type III endoleaks are caused by migration or disintegration of one of the components of the endoprosthesis; and type IV endoleaks are related to porosity of the graft wall. ${ }^{4}$ Type II endoleaks are the most common type and have an incidence of 10 to $25 \%$ over 3 -month follow-up after EVAR is performed. ${ }^{5-7}$

While many studies demonstrate a significant risk of rupture associated with types I and III endoleaks and recommend that they be treated systematically, there is not yet consensus on management of patients with type II endoleaks. The majority of authors suggest that if the aneurysm does not expand, then watchful waiting is the best option. In contrast, if the aneurysm sac grows or persists, procedures such as translumbar or endovascular embolization or even surgical ligature are generally recommended..$^{8-10}$

The effectiveness of procedures varies depending on the techniques and materials employed, which makes it difficult to establish a consensus on the best treatment option for type II endoleaks..$^{11}$ In view of this, the objective of this study was to determine whether there are any factors that are predictive of successful treatment of type II endoleaks related to surgical access route, materials used for embolization, the type of repair technique originally used to treat the aneurysm or the profile of the vascularization supplying the endoleak.

\section{METHOD}

This is a retrospective study based on analysis of medical records filed at the Parkland Memorial Hospital, University of Texas Southwestern Hospital and VA Medical Center, dated from 2003 to 2015 relating to 31 patients and a total of 41 procedures for embolization of type II endoleaks.
The indications for intervention were a persistent type II endoleak lasting more than 6 months or expansion of the aneurysm sac by more than $5 \mathrm{~mm}$. Patients underwent procedures to embolize the aneurysm sac and/or the vessels supplying the endoleak with liquid embolization systems such as Onyx ${ }^{\circledR} 18$ and Onyx ${ }^{\circledR} 34$, coils, Amplatzer ${ }^{\circledR}$ plugs, thrombin or varying combinations of these materials. Embolizations were conducted using translumbar or endovascular approaches. Endovascular access was obtained via the femoral artery, with the endoleak approached via the internal iliac artery (IIA) or the superior mesenteric artery (SMA), depending on the most favorable anatomy in each case. Technical success was defined as no need for reintervention. The chi-square test and Fisher's exact test were used for statistical analysis. The level of statistical significance was set at $95 \%(\mathrm{p}<0.05)$.

\section{RESULTS}

The mean age of patients was 75 years [interquartile range $(\mathrm{IQR})=68-82$ years], 87.1\% (27) were men and $12.9 \%$ (4) were women. From the total sample of 31 patients, $16.1 \%(5)$ had had their abdominal aortic aneurysms (AAA) treated by fenestrated endovascular aortic aneurysm repair (FEVAR) and $83.9 \%$ (26) by EVAR. The mean follow-up time from AAA repair to intervention for treatment of type II endoleaks was 14 months (IQR $=8.5-30.5$ months).

After the first intervention for treatment of type II endoleak, 35.4\% (11) of patients needed reintervention. However, just 10 patients actually underwent this second procedure, since one patient died from an unrelated cause. The mean follow-up time from first embolization to reintervention was 5.5 months (IQR, 4-37 months). Two of these reinterventions $(20 \%)$ did not achieve total resolution of the endoleak during the procedure. Of this series, $12.9 \%$ (4) of the patients died from causes unrelated to the type II endoleaks and $6.4 \%$ (2) were lost to follow-up after the first intervention to correct endoleaks.

Of the total of 41 procedures conducted, $34.15 \%$ (14) were performed via translumbar access, $63.41 \%$ (26) via the femoral artery and $2.44 \%$ (1) using a combination of both accesses. With regard to the embolization materials employed, the most common was Onyx ${ }^{\circledR} 18$, employed in isolation in $36.59 \%$ (15). The remaining materials employed and their respective combinations and frequencies can be consulted in Table 1.

In the statistical analysis of type II endoleak embolization success rates in relation to these 
different types of materials, Onyx ${ }^{\circledR} 18$ and 34 were compared to each other, the use of these materials in combination with coils was compared with its use in isolation, and the use of coils in isolation was compared with the use of Ony ${ }^{\circledR}$ in isolation. None of these comparisons revealed any statistically significant differences whatsoever.

With relation to the access route employed to correct the endoleak, the success rate via translumbar access was $78.57 \%$ (11), compared with $73.08 \%$ (19) when access was achieved via the femoral artery. Notwithstanding, this difference was not considered statistically significant $(p=0.07)$, demonstrating that access route was not a factor predictive of procedure success in this sample. Moreover, the type of repair initially used to treat the AAA (FEVAR or EVAR) also had no influence whatsoever on the outcome of endoleak treatment.

The only factor predictive of success was the artery supplying the endoleak. The success rate was $71.43 \%$ (10) when the lumbar arteries were the source of filling, $80 \%$ (8) if the IMA was the culprit and $40 \%$ (2) if both the lumbar arteries and the IMA were supplying the endoleak $(\mathrm{p}<0.05)$ (Figure 1).

Table 1. Materials employed in embolization of Type II endoleaks.

\begin{tabular}{lc}
\hline \multicolumn{1}{c}{ Embolization Material } & Percentage of patients \\
\hline Onyx ${ }^{\circledR} 18$ & $36.59 \%(15)$ \\
Onyx ${ }^{\circledR} 34$ and Coils & $17.07 \%(7)$ \\
Onyx ${ }^{\circledR} 34$ & $14.63 \%(6)$ \\
Onyx ${ }^{\circledR} 18$ and Coils & $9.76 \%(4)$ \\
Onyx $^{\circledR} 18$, Ony ${ }^{\circledR} 34$ and Coils & $9.76 \%(4)$ \\
Coils and thrombin & $7.32 \%(3)$ \\
Coils & $2.44 \%(1)$ \\
Amplatzer ${ }^{\circledR}$ vascular plug & $2.44 \%(1)$ \\
\hline
\end{tabular}

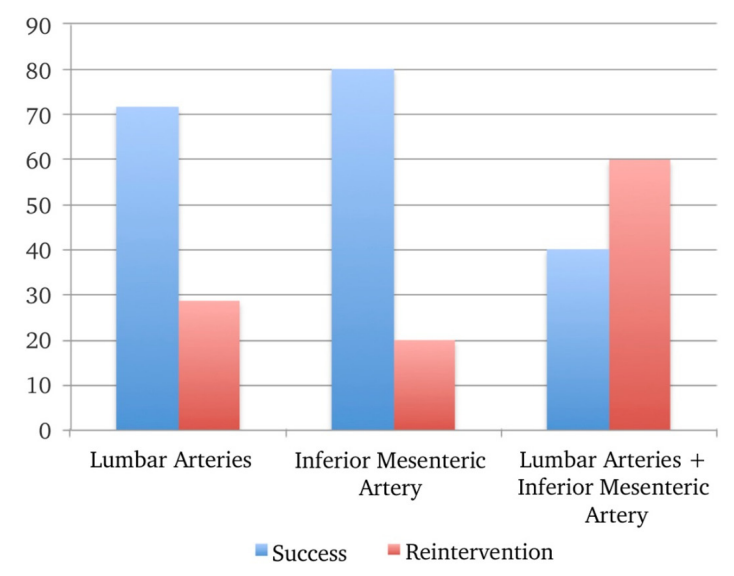

Figure 1. Success rates of embolization of type II endoleaks, by which arteries supply the endoleak.

\section{DISCUSSION}

The objective of treatment of an AAA is to isolate it from blood flow, preventing it from growing and reducing the risk of rupture. ${ }^{3}$ Blood leaking into a previously treated aneurysm is primarily seen after endovascular repair and can cause a persistent risk of rupture, despite treatment having been performed. This risk means that it is necessary to maintain regular follow-up of patients treated with EVAR in order to detect and treat potential endoleaks. ${ }^{1-3}$

Type II endoleaks are the most common of the endoleak subtypes and they are the result of continued patency of arterial branches that emerge from the aneurysm and can cause retrograde perfusion of the aneurysm and, in some cases, cause the sac to expand. ${ }^{1,2}$ This can occur even if there is only one branch filling the sac, but it is common for several patent branches to be present. The most common anatomic origins of this type of endoleak are the lumbar arteries and the IMA. ${ }^{1,2,4}$

To date there is still no universally accepted method for managing these endoleaks. A recent multicenter study that analyzed 1,736 patients treated with EVAR, 474 of whom developed type II endoleaks, did not detect an increase in the aneurysm-related mortality rate associated with the presence of a type II endoleak, even when patients with endoleak and expansion of the aneurysm sac who were only monitored were compared with patients who underwent interventions to correct leaks. ${ }^{12}$

Hajibandeh et al. conducted a meta-analysis and they also reported that rupture of an aneurysm due to a type II endoleak in isolation is rare. However, they also concluded that more long-term prospective studies are needed to better evaluate the subject. ${ }^{13}$

In those cases in which the decision is taken to intervene in a type II endoleak, there are several different ways of doing so. Some authors recommend embolization of vessels supplying the leak, while others prefer embolization of the aneurysm sac itself. ${ }^{1,4}$ With relation to route of access, the options available are translumbar embolization, endovascular embolization or even surgical ligature of the vessel responsible. Additionally, several different materials are available to seal the vessel supplying the leak, such as coils, Onyx ${ }^{\circledR}$, Amplatzer $^{\circledR}$ and thrombin, among others, and they can be used individually or in different combinations (Figure 2) ${ }^{1,4}$

Percutaneous transarterial embolization is the intervention most frequently used to treat Type II endoleaks. ${ }^{1,14}$ It is generally performed via femoral access, and the vessel responsible for the endoleak can 


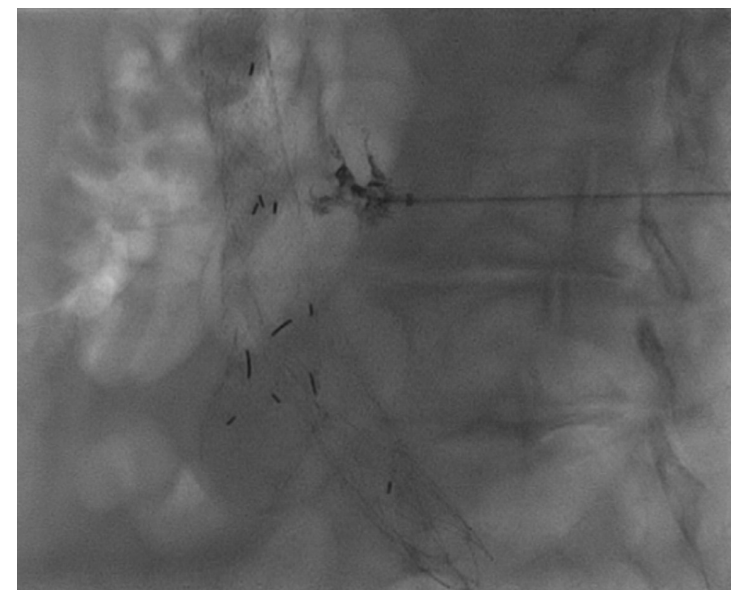

Figure 2. Embolization of type II endoleak via translumbar access using Ony $x^{\circledR} 18$.

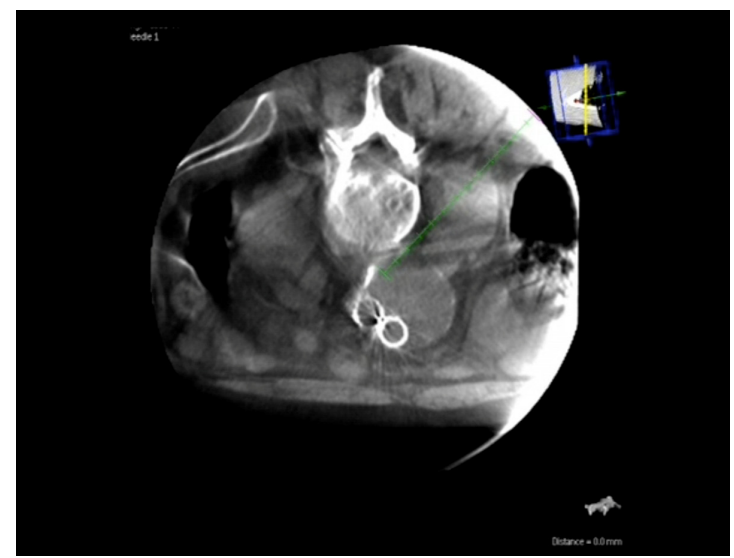

Figure 3. Embolization of type II endoleak via translumbar access. Calculating trajectory with three-dimensional computed tomography in real time. The ideal trajectory of the needle is determined by the vascular surgeon marking the endoleak as the target and taking care to avoid vital anatomic structures.

be reached by catheterization of the IIA or the SMA. ${ }^{1}$ Translumbar embolization is a form of minimally invasive treatment, with short procedure time and limited use of contrast mediums, and is an alternative option that is particularly useful when transarterial access is impossible (Figure 3). ${ }^{1,15}$

There is no consensus in the literature on which of these two access options (transarterial or translumbar) has the highest success rates. The majority of studies report better results for the translumbar approach, with lower rates of recurrence and fewer complications. ${ }^{1,2}$ However, as a general rule, the translumbar method is used as a second line treatment, after the transarterial method has failed, introducing a bias to analysis of the results. ${ }^{1}$ On the other hand, Stavropoulos et al. ${ }^{16}$ conducted a study in which the results were similar when these two approaches were compared, which was also observed among the patients analyzed for the present study. Similarly, analysis of the different materials employed for embolization did not detect any statistically significant difference between materials that was indicative of superiority, which has also been reported by other studies in the literature. ${ }^{14}$

Some references subdivide type II endoleaks into IIa or simple, when there is just one patent branch supplying the leak, and type IIb or complex, when two or more branches are supplying blood..$^{15}$ Normally, simple Type II endoleaks are self-limiting, whereas complex endoleaks may persist and cause the aneurysm sac to expand. ${ }^{15}$

In the present study, the only factor predictive of successful embolization of Type II endoleaks was which artery was supplying the endoleak, with a significantly lower success rate when both lumbar arteries and IMA were involved.

\section{CONCLUSIONS}

Treating type II endoleaks remains a challenge, with reintervention needed in approximately $36 \%$ of cases. There are no statistically significant differences between the different techniques or the materials employed to treat this condition. The only factor predictive of success identified in this sample of patients was the artery supplying blood to the endoleak. More in-depth investigations of the treatments for Type II endoleaks are still needed to define the best method and the best time to repair them.

\section{REFERENCES}

1. Avgerinos ED, Chaer RA, Makaroun MS, Type II. Endoleaks. J Vasc Surg. 2014;60(5):1386-91. http://dx.doi.org/10.1016/j.jvs.2014.07.100. PMid:25175637.

2. Stather PW, Sidloff D, Dattani N, Choke E, Bown MJ, Sayers RD. Systematic review and meta-analysis of the early and late outcomes of open and endovascular repair of abdominal aortic aneurysm. Br J Surg. 2013;100(7):863-72. http://dx.doi.org/10.1002/bjs.9101. PMid:23475697.

3. Paravastu SC, Jayarajasingam R, Cottam R, Palfreyman SJ, Michaels JA, Thomas SM. Endovascular Repair of Abdominal Aortic Aneurysm. Cochrane Database Syst Rev. 2014;1:CD004178. PMid:24453068.

4. Haulon S, Tyazi A, Willoteaux S, Koussa M, Lions C, Beregi JP. Embolization of type Il endoleaks after aorticstent-graft implantation: Technique andimmediate results. J Vasc Surg. 2001;34(4):600-5. http://dx.doi.org/10.1067/mva.2001.117888. PMid:11668311.

5. Parent FN, Meier GH, Godziachvili V, et al. The incidence and natura history of type I and II endoleak: a 5-year follow-up assessment with color duplex ultrasound scan. I Vasc Surg. 2002;35(3):474-81. http://dx.doi.org/10.1067/mva.2002.121848. PMid:11877694.

6. Veith FJ, Baum RA, Ohki T, et al. Nature and significance of endoleaks and endotension: summary of opinions expressed at 
an international confer- ence. J Vasc Surg. 2002;35(5):1029-35. http://dx.doi.org/10.1067/mva.2002.123095. PMid:12021724.

7. Waasdorp E, van Herwaarden JA, van de Mortel RH, Moll FL, de Vries JP. Early computed tomographic angiography after endovascular aneurysm re- pair: worthwhile or worthless? Vascular. 2008;16(5):253-7. http://dx.doi.org/10.2310/6670.2008.00034. PMid:19238865.

8. Van Marrewijk CJ, Fransen G, Laheij RJF, et al. Is a type II endoleak after EVAR a harbinger of risk? Causes and outcome of open conversion and aneurysm rupture during follow-up. Eur J Vasc Endovasc Surg. 2004;27:128e37.

9. Steinmetz E, Rubin BG, Sanchez LA, et al. Type II endoleak after endovascular abdominal aortic aneurysm repair: a conservative approach with selective intervention is safe and cost-effective. J Vasc Surg. 2004;39:306e13.

10. Rayt HS, Sandford RM, Salem M, et al. Conservative management of type 2 endoleaks is not associated with increased risk of aneurysm rupture. Eur J Vasc Endovasc Surg. 2009;38:718e23.

11. Nevala T, Biancari F, Manninen $\mathrm{H}$, et al. Type II endoleak after endovascular repair of abdominal aortic aneurysm: effectiveness of embolization. Cardiovasc Intervent Radiol. 2010;33:278e84.

12. Walker J, Tucker LY, Goodney P, et al. Type II endoleak with or without intervention after endovascular aortic aneurysm repair does not change aneurysm-related outcomes despite sac growth. J Vasc Surg. 2015;62(3):551-61. http://dx.doi.org/10.1016/j. jvs.2015.04.389. PMid:26059094.

13. Hajibandeh S, Ahmad N, Antoniou GA, Torella F. Is intervention better than surveillance in patients with type 2 endoleak postendovascular abdominal aortic aneurysm repair? Interact Cardiovasc Thorac Surg. 2015;20(1):128-34. http://dx.doi.org/10.1093/icvts/ ivu335. PMid:25301297.

14. Jouhannet C, Alsac JM, Julia P, et al. Reinterventions for type 2 endoleaks with enlargement of the aneurismal sac after endovascular treatment of abdominal aortic aneurysms. Ann Vasc Surg. 2014;28(1):192-200. http://dx.doi.org/10.1016/j.avsg.2012.10.038. PMid:24200135.
15. Van Bindsbergen L, Braak SJ, van Strijen MJL, de Vries JPPM, Type II. Endoleak embolization after endovascular abdominal aortic aneurysm repair with use of real-time three-dimensional fluoroscopic needle guidance. J Vasc Interv Radiol. 2010;21(9):1443-7. http:// dx.doi.org/10.1016/j.jvir.2010.05.016. PMid:20708410.

16. Stavropoulos SW, Park J, Fairman R, Carpenter J. Type 2 endoleak embolization comparison: translumbar embolization versus modified transarterial embolization. J Vasc Interv Radiol. 2009;20(10):1299302. http://dx.doi.org/10.1016/j.jvir.2009.07.003. PMid:19695902.

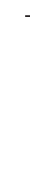

